DOI: http://doi.org/10.22364/ruslat.glp.05

\title{
Элина Круповича
}

\section{Приходская жизнь Рижской церкви Всех Святых до 1914 года}

Рижская церковь Всех Святых расположена на территории бывшего Московского форштадта. В 1777 году на территории кладбища в районе нынешних улиц Католю, $\Lambda$. Кална, Ааугавпилс на территории кладбища была построена часовня во имя Всех святых, и кладбище получило название Всехсвятского. Эту Аату можно считать началом истории Всехсвятской церкви. В 1812-1814 годах на месте часовни была построена деревянная церковь, приписанная к Рижской Благовещенской церкви. В 1852 году Всехсвятская церковь становится самостоятельным приходским храмом. В 80-90х годах 19 века начинается новый этап в развитии архитектурного ансамбмя церкви: завершено строитемьство нового каменного зАания церкви (1884 г.) и построено зАание церковно-приходской школы (1892 г.). К началу Первой мировой войны Всехсвятская церковь была крупным религиозно-просветительским центром преАместья ${ }^{1}$.

Ключевые слова: Рига, Московский форштадт, русское население Риги, православные приходы, приходская жизнь

\section{Из истории формирования архитектурного ансамбля церкви}

Рижская церковь Всех Святых расположена на улице Католю, 10, на территории старейшего преАместья Риги - Московского форштаАта ${ }^{2}$. Аокументальные сведения о наличии первой в Риге православной церкви во имя Св. Николая Чудотворца и клаАбища при ней относятся к 1453 году. ОАнако храм был сооружен значительно раньше, видимо, около 1229 года, когда в Риге появилась колония (Авор) купцов из Аревнерусских земель. Рижская Св. Николаевская церковь функционировака только метом, когАа в город приезжали русские купцы. В 1616 году зАание церкви еще существовало, однако после занятия в 1621 году Риги швеАами больше в письменных источниках не упоминается. ВиАимо, к этому времени зАание

1 В Аанной статье история приходской жизни церкви Всех Святых до 1914 года отображена на основе материалов периодической прессы, изданных до 1914 года. Истории приходской жизни церкви Всех Святых в 20-30-е годы XX века посвящена отдельная статья, основанная на периодических изАаниях 20-30-х годов. Подробнее см.: Круповича 2005: 201-207.

2 Ао 1934 года предместье носимо название Московского форштадта, потом было переименовано в $\Lambda$ атгальское предместье. 
Св. Николаевской церкви было уже разобрано. Неизвестен ни внешний виА этого храма, ни его планировка, ни Ааже точное место его расположения (предположительно, храм находился в районе улиц М. Трокшня и Атгриежу). Аругих православных храмов на территории Иифмяндии до 18 века не было. В 1715 году рядом с городскими укреплениями, неАалеко от Кармовских ворот, на среАства, пожертвованные русскими купцами Риги, была построена Аеревянная церковь во имя БАаговещения Пресвятой Богородицы с приделом во имя Св. Николая Чудотворца. Уже в 1773 году в связи с сооружением новых фортификационных сооружений вокруг Риги зАание этой церкви бымо разобрано, а из её материалов на православном кладбище Риги (в районе нынешних улиц Католю, $\Lambda$. Кална, Ааугавпилс) в 1777 году была построена часовня (Гаврилин 2001: 79, 80, 86). Часовня была освящена во имя Всех Святых и само кмадбище стало называться Всехсвятским (Вахрамеев 1912: 304).

Русское купечество Риги осталось без своего храма, поэтому было принято решение на Московском форштадте, в районе так называемого «Гостиного Авора» и скиадов русских купцов (в районе улицы Гоголя) отвести место Аля строительства новой церкви. Аеревянная «русско-рынская» Благовещенская церковь была построена в 1774-1778 годах (Гаврилин 2001: 86, 87). ОАнако вскоре часовня во имя Всех Святых стала не вмещать всех момящихся. Поэтому в 1812 году рядом со Всехсвятской часовней начинается строительство церкви. К мету 1812 года зАание уже бымо подведено поА крышу. В 1812 году Благовещенская церковь сгорела, но её церковную утварь успели перенести в ещё недостроенную Всехсвятскую церковь. Строительство церкви продолжили сразу же посме окончания Отечественной войны 1812 года. При Всехсвятской церкви в 1814 году был основан приход. В 1815 году храм быи освящён во имя Всех Святых (Вахрамеев 1912: 304). Немецкий историк В. Гутцейт так описывал церковь Всех Святых: построена в византийском стиле, деревянная, на высоком фундаменте, с одним главным и четырьмя боковыми куполами, с отдельно стоящей колокольней (Gutzeit 1868: 411). 10 июня 1814 года на месте сгоревшей Рижской Благовещенской церкви была заложена новая деревянная церковь на каменном фундаменте, также во имя БАаговещения Пресвятой Богородицы ${ }^{3}$ (Гаврилин 2001: 88).

В 1852 году приход Рижской церкви Всех Святых, ранее приписанный к Рижскому Благовещенскому приходу, стал самостоятельным приходом. Большая часть прихожан Благовещенского прихода была приписана ко Всехсвятской церкви. Приходу церкви Всех Святых был назначен штатный причт, состоящий из священника, Аьякона и Авух псаломщиков (Вахрамеев 1912: 304).

3 ЗАание церкви сохранилось до наших дней и находится в Риге по аАресу умица Гоголя, 9. 
В 80-90-х годах 19 века начинается новый этап в развитии архитектурного ансамбля церкви во имя Всех Святых. Рижская Ауховная консистория 15 октября 1881 года заказала архитектору Янису Фридриху Бауманису ${ }^{4}$ разработку проекта нового храма с составмением эскизов на перенос старой деревянной Всехсвятской церкви «как она есть» на Ивановское кладбище (АГИА-10). В 1882 году деревянный храм разбирают и переносят на Ивановское кАадбище. Там храм собирают снова и по решению Рижской Ауховной консистории приписывают ко Всехсвятскому приходу ${ }^{5}$ (Гамлер 1884). 22 августа 1882 года на месте бывшей деревянной церкви закладывается новое кирпичное зАание. Через два года строительство было завершено. В начале 1888 года епископ Рижский и Митавский Арсений (Брянцев $)^{6}$, осматривая церкви Риги, «выразил своё удовольствие при виде обширного храма» (Посещение церквей города Риги Преосвященным Арсением 1888). Настоятель храма отец Григорий Краснянский говорил, что «стоя в храме ... стоишь как бы на небе» (Краснянский 1892: 154). Освящение нового храма во имя Всех Святых состоянось 9 мая 1891 года.

Ко Всехсвятскому приходу относились также три часовни: в воротах Всехсвятского храма, у так называемого «Русского рынка» и на Всехсвятском кладбище. Часовня на кладбище была построена по проекту Яниса Фридриха Бауманиса на средства А.Я. Камариной в византийском стиле: «Стены часовни возведены из серого гранита, внутри облицованы цветным мрамором, купол обложен снаружи цинковыми чешуями, а внутри расписан богатой живописью. В окна по образцу средних веков вставмены разноцветные стёкла, а вхоА закрывается решётчатыми Аверьми. На

4 Янис Фридрих Бауманис (1834-1891) известный мифмяндский архитектор; первый архитектор-латыш, получивший высшее образование и ставший основоположником национальной архитектуры. С 1870 года по 1880 гоА работал архитектором

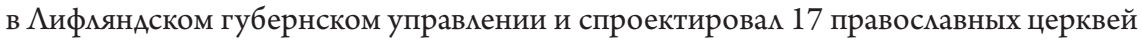
на территории Аифмянаской губернии.

511 сентября 1883 года епископ Рижский и Митавский Аонат (Соколов-Бабинский) освятил церковь в память усекновения честной главы св. Пророка и Предтечи Крестителя Господня Иоанна. В 1892 году так называемая Ивановская церковь была отделена от Всехсвятской церкви. Это зАание сохранилось на Ивановском кладбище Ао наших Аней как храм Казанской иконы Пресвятой Богородицы в районе улицы $\Lambda$. Кална, 21.

6 Архиепископ Арсений (Брянцев) (1839-1914) - епископ Рижский и Митавский. За его Аесятилетнее пребывание (с 1887 по 1897 гг.) на Рижской кафеАре было возАвигнуто 67 новых храмов и несколько часовен, образовано 26 новых приходов (общее количество приходов возросло со 169 до 195). Архиепископ ввел духовные беседы с прихожанами, устроил библиотеки и изАал много брошюр духовного соАержания. Его усердием создан Пюхтицкий женский монастырь, а в Риге основана Свято-Троицкая женская община. При всех церквях архиепископ основал библиотеки, широко развернул миссионерские беседы, учредил при духовной семинарии Историко-статистический Комитет по описанию церквей и приходов Рижской епархии. В 1896 году в Риге быи учрежАён Церковно-археологический музей. 
внутренней восточной стене церкви - икона св. мученика Павла, покровитемя П.Г. Камарина, написанная на медной доске в киоте из белого мрамора» (Краснянский 1891: 798).

19 июмя 1892 года рядом со Всехсвятским храмом начинается строительство приходской школы по проекту архитектора А.П. Кизельбаша. Найти необходимые Аля строительства средства помог случай. Благотворитель, пожелавший остаться неизвестным, переАал руковоАству Рижской епархии капитал в размере 100000 рубцей, с тем, чтобы годовые проценты с этого капитала были направлены на строитемьство школы при какой-нибуАь церкви. 11 ноября 1891 года епископ Рижский и Митавский Арсений (Брянцев) благословил выделение 4000 рублей на строительство приходской школы при Всехсвятской церкви (Краснянский 1892: 152).

9 января 1894 года зАание приходской школы (в настоящее время зАание Рижской Ауховной семинарии по аАресу улица Католю, 10) было освящено епископом Рижским и Митавским Арсением (Брянцевым). 3Аание школы было Авухэтажным. На первом этаже находился большой зал Аля общей молитвы и собраний. На втором этаже располагались Ава класса: Аля мальчиков и Аля девочек. Занятия в школе начались уже 15 января (Торжество освящения каменного Авухэтажного зАания и открытия в нём церковно-прихоАской школы 1894: 147).

Таком образом в 90-е годы 19 века завершилось формирование архитектурного ансамбця Всехсвятской церкви.

\section{Приходская жизнь}

В середине 19 века ситуация в области знаний и веры среди православного населения Московского форштадта была крайне сложной. В особенно беАственном положении находияся приход Всехсвятской церкви. «ПрихоА сей находится среАи самого многочисленного населения раскольников, которые, примером своей беспорядочной жизни, пагубно действуют на православных, увлекая их в те же пороки, которым преАаются сами, как то: пьянству, распутству, воровству и т.А. А мюАям при таком безнравственном образе жизни не Ао попечения о Ауше», - такие сведения Аают Аокументы Рижской Ауховной Консистории за 1856 гоА (АГИА-1). В Московском форштадте так же не соблюАалось узаконение, которым воспрещалось в воскресные Ани отпирать трактиры до окончания в церквях Богослужения (АГИА-2). Учитывая социальный состав жителей Московского форштадта (рабочие, ремесленники и т.А.), по документам Рижской Ауховной Консистории за 1854, 1856, 1857 и Ар. г., знания прихожан церквей Московского форштадта о начальных символах веры, заповеАях, молитвах - были неАостаточными (АГИА-5). Чтобы повысить знания прихожан в Ауховной сфере, были введены Катехизисные поучения. Во Всехсвятской церкви они читались еще в 1844 году, когАа она была приписана к Благовещенской церкви. ТогАа их читал священник Благовещенской церкви отец Иоанн Васильевич Преображенский по воскресным и праздничным Аням 


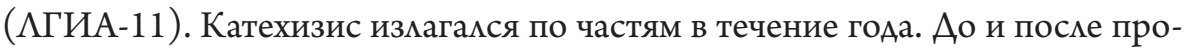
изнесения мекций священник был обязан преАставмять тексты мекций цен-

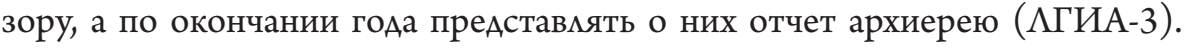
По сведениям Рижской Ауховной консистории, поучения выскушивались Всехсвятским приходом внимательно, но при этом уровень знаний оста-

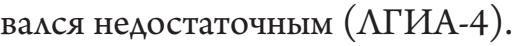

Причт Всехсвятского прихода заботился также о духовном воспитании детей. Аети бедных прихожан, обучающиеся в мютеранских школах, в воскресные и праздничные Ани собирались переА митургией на квартире священника Амя преподания им нужных ААя православного основных истин веры (АГИА-6). В последующие годы во Всехсвятской церкви чита-

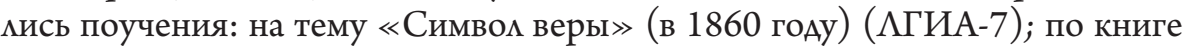
Бытия (в 1862 гоАу) (АГИА-8); по священной истории Ветхого завета (в 1863 году) (АГИА-9) и Ар.

Во Всехсвятской церкви проходили также и миссионерские бесеАы, например, 21 марта 1890 года проходили бесеАы синодального миссионера протоиерея Ксенофонта Крючкова (Епархиальная хроника 1890: 262).

В конце 1890 года по решению епископа Арсения (Брянцева) были открыты внебогоскужебные чтения при Всехсвятской церкви (Краснянский 1890: 723). Они Аолжны были проводиться по воскресным и праздничным Аням. Эти чтения отличались от обыкновенной проповеди тем, что они были более пространными, предмет изучения должен был быть рассмотрен всесторонне; в случае непонимания, аудитория могла задавать вопросы. Цель чтений состояла в религиозно-нравственном просвещении прихожан посреАством разъяснения истин веры и правил православно-христианской жизни. Чтения начались 18 ноября 1890 года. Традиция внебогоскужебных чтений привилась и в последующие годы. Так, 14 октября 1912 года были открыты очередные чтения (Религиозно-нравственные беседы в г. Риге 1913: 88). 22 октября 1912 года состоянась беседа дьякона К. Аорина на тему «Богоматерь и Россия». Епископ Рижский и Митавский Иоанн (Смирнов) разАавал брошюру Иринея ОрАы поА названием «О мживости уверения, что религия - частное, Аичное Аело кажАого». В слеАующие воскресенья были продомжены беседы на темы: 1) об иерархии (свящ. Н. Павель); 2) о священном писании (прот. В. Пиисс); 3) «об условиях спасения по учению Православной Церкви в связи с католическим и протестантским учением о свободе и благодати» (прот. В. Березский). Как сообщали «Рижские епархиальные ведомости», эти чтения отвечали запросам слушателей. КажАая беседа сопровожАалась общим одушевленным пением (Религиозно-нравственные беседы в г. Риге 1913: 88).

В 1914 году в Риге при Всехсвятской церкви были открыты народно-миссионерские курсы (Круповича 1914а: 97). Можно предположить, что Всехсвятская церковь была выбрана Аля этой миссии потому, что по утвержАению настоятемя церкви отца Г. Краснянского в 1892 году: «Всехсвятский приход есть самый многочисленный не только в городе Риге, но и 
во всей Рижской епархии» (Краснянский 1892: 154). Это положение не изменилось к 1914 году. Численность населения Московского форштадта увемичилась в связи с увеличением объема производства на фабрике по производству фаянсовой посуды купца С.Т. Кузнецова, Балтийской мьняной мануфактуре в Кенгарагсе и Ар. В пользу Всехсвятской церкви смогло сыграть и то, что она обладама нужными Аля курсов помещениями (зАанием церковно-приходской школы, построенным в 1894 году), а также квалифицированным и почитаемым прихожанами составом причта.

7 января 1914 года архиепископ Иоанн (Смирнов) в своем назидательном слове отметил, что на курсах главным образом будут разъясняться истины, подвергающиеся сомнению и отрицанию со стороны старообрядцев и сектантов (Круповича 1914а: 98). В первый Аень на курсы записалось около 200 человек. ПреАполагалось проводить занятия по вторникам и четвергам с 8 до 10 часов вечера. Расписание курсов было таким: по вторникам - чтения, объяснение посланий св. Апостолов (лектор свящ. о. А. Клинентовский), история и обличение раскола (лектор прот. о. В. Плисс), пение церковных песнопений (свящ. о. А. Андреев); по четвергам - чтение и объяснение св. Евангелия (лектор свящ. о. В. Церинь), история и обличение сектанства (Аектор свящ. о. И. Павель), пение духовных песнопений (свящ. о. А. Анареев) (Круповича 1914b: 53).

9 января состоялась первая мекция. На этом занятии присутствоваци 224 человека. Количество слушателей к 30 января Аостигло 332 человек. Как сообщали «Рижские епархиальные ведомости», все эти слушатели еАва вмещались в помещениях Всехсвятской приходской школы (Круповича 1914а: 98). Они со вниманием и интересом выслушивали беседы и чтения. Особенное оживление наступало тогАа, когАа начинацись церковные песнопения под руководством свяш. отца А. Анареева. Песнопения с УАОвольствием исполнялись и Аетьми, и АюАьми зрелого возраста. ААя того, чтобы их можно было петь не только на курсах, но и Аома, слушатели приобрели 300 экземпляров «Церковных песнопений». Кроме этих книжек, слушатели приобретали также книги Нового Завета и руководства Аля обмичения старообрядчества и сектанства» (Круповича 1914а: 99).

Архиепископ Иоанн (Смирнов) обычно присутствовац на всех курсах и сам выступам в качестве мектора. 28 января на курсах присутствовал священник англиканской церкви доктор Богословия Вальтер Фриер, приехавший из Англии с целью ознакомления с жизнью и обычаями Русской Православной церкви. Сам факт присутствия его на курсах говорит об их попумярности.

13 февраля на курсах присутствовах Полоцкий епархиальный миссионерский священник о. Киримл Зайц, приехавший специально Аля ознакомления с народно-миссионерскими курсами (Круповича 1914а: 176). По Аанным на 26 февраля в феврале количество слушателей Аостигло 438 человек. 
В марте занятия отличались особым оживлением. Успеху курсов способствовали доклады бывшего баптистского наставника Ф.А. Буцена, ставшего православным епархиальным миссионером, и перешедшего в православие католического священника о. Б.А. Ковалевского. Самое большое количество слушателей было 12 марта (свыше 500 человек).

Занятия в апреле и мае проходили обычным чередом. В этот периоА курсы посетили: старший цензор Ауховной цензуры архиманАрит Александр из Санкт-Петербурга и также священники из Сааремаа, Тукумса и т.А. (Круповича 1914a: 341). Это свидетельствовало о росте популярности курсов среАи православного духовенства.

12 мая скушатели курсов в знак благодарности за организацию курсов поднесли архиепископу Иоанну (Смирнову) икону св. Евангелиста Иоанна Богослова (Круповича 1914а: 508). Аетом занятия посещались также охотно, проходили один раз в неделю. КажАый день занятия посещало от 250 Ао 300 человек (Круповича 1914а: 341).

Начало Первой мировой войны прервало не только традицию народно-миссионерских курсов, но и приходскую жизнь Всехсвятской церкви в целом. Тем не менее к началу Первой мировой войны Всехсвятская церковь была крупным религиозно- просветительским центром Московского форштадта.

\section{Источники}

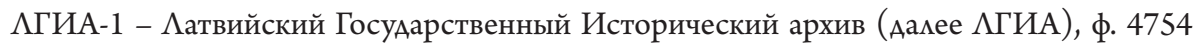
(Рижская Ауховная консистория), оп. 1, А. 185, ^. 14.

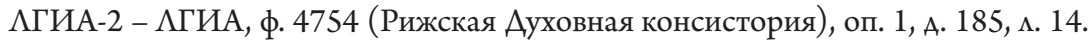

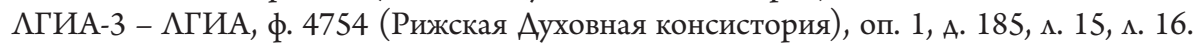

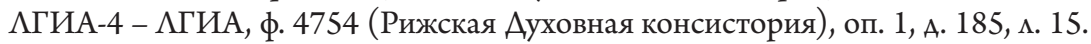
АГИА-5 - АГИА, ф. 4754 (Рижская Ауховная консистория), оп. 1, А. 188, м. 33. АГИА-6 - АГИА, ф. 4754 (Рижская Ауховная консистория), оп. 1, А. 188, м. 33. АГИА-7 - АГИА, ф. 4754 (Рижская Ауховная консистория), оп. 1, А. 191, м. 23. АГИА-8 - АГИА, ф. 4754 (Рижская Ауховная консистория), оп. 1, А. 197, ^. 6. $\Lambda$ ГИА-9 - АГИА, ф. 4754 (Рижская Ауховная консистория), оп. 1, А. 198, ^. 30. $\Lambda$ КИА-10 - АГИА, ф. 4754 (Рижская Ауховная консистория), оп. 1, А. 228, м. 42.

$\Lambda$ ГИА-11 - АГИА, ф. 7462 (Канцемярия епископа Рижского и Митавского), оп. 1, А. 1,

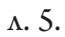

\section{Литература}

Вахрамеев, Г. (1912). К преАстоящему 100-летию Рижской Благовещенской церкви. Рижские епархиальные ведомости, 1 мая. С. 304.

Гаврилин, А.В. (2001). Строительство православных храмов на территории Аатвии до середины XIX века. В: Православие в Һатвии. Исторические очерки 3. Сборник научных статей под редакцией А.В. Гаврилина. Рига: Филокалия. С. 79-80, 86-88. Гамлер, К. (1884). Православные церкви в Риге. Рижский вестник. 27 октября. (1890). Епархиальная хроника. Рижские епархиальные ведомости, выпуск 8. С. 262. 
Краснянский, Г. (1890). Поучение по поводу открытия внебогослужебных чтений или собеседований во Всехсвятской церкви города Риги, сказанное 18 ноября 1890 года. Рижские епархиальные ведомости, выпуск 23. С. 723.

Краснянский, Г. (1891). Поучение по поводу освящения наАмогильного памятникачасовни на Всехсвятском кладбище города Риги. Рижские епархиальные ведомости, выпуск 23. С. 798.

Краснянский, Г. (1892). Поучение по поводу возобновления выбора чиенов Всехсвятского церковно-приходского попечительства в г. Риге, произнесенное 19 января 1892 года. Рижские епархиальные ведомости, выпуск 4. С. 152, 154.

Круповича, Э. (1888). Посещение церквей города Риги Преосвященным Арсением. Рижские епархиальные ведомости, выпуск 3.

Круповича,Э.(1894). Торжество освящения каменногодвухэтажного здания и открытия внёмцерковно-приходскойшколы. Рижскиеепархиальныеведомости, выпуск 4.С. 147.

Круповича, Э. (1913). Религиозно-нравственные беседы в г. Риге. Рижские епархиальные ведомости, выпуск 3. С. 88.

Круповича, Э. (1914а). Народно-миссионерские курсы в г. Риге. Рижские епархиальные ведомости, выпуск 4. С. 97-99, 176, 341, 508.

Круповича, Э. (1914b). Открытие православных народно-миссионерских курсов. Рижские епархиальные ведомости, выпуск 2. С. 53.

Круповича, Э. (2005). Рижская церковь Всех Святых как центр культуры Аатгальского предместья в 20-20-е годы XX века. Rusistica Latviensis 5. Slavica - 2015: filologijas pètējumi. Rīga: LU Akadēmiskais apgads. C. 201-207.

Gutzeit, W. (1868). Mittheilungen aus dem Gebiete der Geschichte Liv. - Ehst. - Kurlands. Riga: Nicolai Kymmels Buchhandlung. Band 11. S. 411.

\section{Rīgas Visu Svēto baznīcas draudzes dzīve līdz 1914. gadam}

Rīgas Visu Svēto baznīca atrodas bijušās Maskavas priekšpilsētas teritorijā. 1777. gadā kapsētas teritorijā tagadējo ielu - Katol̦u, Lielā kalna un Daugavpils ielas rajonā tika uzbūvēta kapliča, ko nosauca Visu Svēto vārdā, un tad arī kapsēta ieguva Visu Svēto kapsētas nosaukumu. Šo gadu var uzskatīt par Visu Svēto baznīcas vēstures sākumpunktu. 1812.-1814. gadā kapličas vietā tika uzcelta koka baznīca, kas piederēja Rīgas Marijas pasludināšanas baznīcas draudzei. 1852. gadā Visu Svēto draudze kḷuva par neatkarīgu draudzi. 19. gadsimta 80.-90. gados sākās jauns posms baznīcas arhitektūras ansambļa izveidē: tika uzcelta jauna akmens baznīcas èka (1884. g.) un draudzes skolas èka (1892. g.). 19. gadsimta otrajā pusē un 20. gadsimta sākumā Visu Svēto draudzē regulāri notika katķisma mācības, misionāru pārrunas un ārpusdievkalpojumu lasījumi. 1914. gadā draudzē tika atklāti misionāru kursi. Pirmā pasaules kara sākums pārtrauca Visu Svēto baznīcas draudzes dzivi, tomēr pirms tam Visu Svēto baznīcas draudze bija izveidojusies par nozīmīgu Maskavas priekšpilsētas reliǵijas un izglītỉbas centru.

\section{The All Saints Orthodox Parish of Riga until 1914}

The Riga's All Saints Church is located on the territory of the former so-called Moscow suburb (Maskavas forštate). In 1777, a chapel in the name of All Saints was built on the territory of the cemetery in the area of the present day Katolu, L. Kalna and Daugavpils streets, and the cemetery was named the All Saints. This date can be considered as the beginning of the history of the All Saints Church. In 
1812-1814, a wooden church was built instead of the chapel, and it was attributed to the Annunciation Church of Riga. In 1852, the Church of All Saints became an independent parish church. A new stage in the development of the architectural ensemble of the church began in $80 \mathrm{~s}-90 \mathrm{~s}$ of the $19^{\text {th }}$ century: the construction of a new stone church building was completed (1884), and the parish school was built (1892). By the beginning of the First World War, the All Saints Church was a major religiouseducational centre in the suburbs. 